\title{
Effect of Marination with Fruit and Vegetable Juice on the Some Quality Characteristics of Turkey Breast Meat
}

EAuthor(s)

\section{Gök V'}

Bor $Y^{\prime}$

Faculty of Engineering, Food Engineering Department, Afyon Kocatepe University, Afyonkarahisar, Turkey

\section{nail Address}

Corresponding author e-mail address Veli Gök

Engineering Faculty, Food Engineering Department, Afyon Kocatepe University,

Ahmet Necdet Sezer Camp., Gazligöl

Street, Afyonkarahisar, 03200, Turkey

Ph: 0090272281423

Fax: 0090272281422

Email: veligok@hotmail.com

\section{- Keywords}

Antioxidant, marination, phenolic compounds, turkey meat, texture.

\section{ABSTRACT}

The effect of marination with antioxidant-rich fruit and vegetable juices, including black carrot juice, black mulberry juice, black grape and pomegranate juice, mixed vegetable juice (yellow carrot, tomato, zucchini, pepper, black carrot, cucumber and lettuce) for 24 and 48 hours on chemical, textural and sensorial properties of turkey breast meat was investigated. Moisture content of the samples marinated for 24 hours and cooked varied between 58.85 and $70.51 \%$, with the control sample presenting the moisture highest value. The samples marinated in red grape juice for 48 hours had the highest cooking loss $(49.11 \%)$, while the lowest cooking loss was recorded in the samples marinated in black carrot juice $(40.61 \%)$. Moreover, the phenolic content of the samples marinated for 24 hours (250.12-1354.76 mg $\mathrm{ga} / \mathrm{L})$ was higher than those marinated for 48 hours (210.56-1156.43 $\mathrm{mg} \mathrm{ga/L).} \mathrm{Reduced} \mathrm{hardness} \mathrm{values} \mathrm{were} \mathrm{obtained} \mathrm{in} \mathrm{turkey} \mathrm{breast} \mathrm{meat}$ marinated in pomegranate $(1.36 \mathrm{~kg})$ and red grape $(0.86 \mathrm{~kg})$ juices, suggesting that these juices may potentially to be used as processing ingredients. Marination for 48 hours promoted better sensorial properties than marination for 24 hours.

\section{INTRODUCTION}

The association between good health and eating habits have led people to pay more attention to their daily eating habits, or diets, which consist of different components. In this aspect, the consumption of foods that promote good health is preferred, provided that these foods are economically affordable. From this point of view, turkey meat is an attractive source that can be compared with beef in terms of nutritional value (Sipahi, 2006).

Turkey meat is a protein source of animal origin that can be safely consumed by people of different ages because of its highly nutritious content. Since the fat is mainly located under the skin, turkey muscle fat content is low. Therefore, fat intake when consuming turkey meat is not high when the skin is not consumed. While the cholesterol content of beef and lamb is $68 \mathrm{mg} / 100 \mathrm{~g}$ and $71 \mathrm{mg} / 100 \mathrm{~g}$, respectively, turkey breast meat contains $65 \mathrm{mg} / 100 \mathrm{~g}$ cholesterol (işseri, 2007). Turkey meat contains less unsaturated fat than beef and pork (Stadelman et al., 1988). Amino acids, such as alanine, serine, aspartic acid, methionine, glutamic acid, and tyrosine are present, and lysine content, for which the need of children is 2.5-3.5 times higher than for adults, of turkey meat is high (Masiero, 1993). Moreover, it contains minerals, such as iron, zinc, copper, potassium, magnesium, phosphorus and manganese, and vitamins, including ascorbic acid, thiamine, riboflavin, pentatonic acid, $B_{6}, B_{12}$ and Vitamin A (Özbay, 2009). 
Although the nutritive value of turkey meat is high, its consumption is limited. One of the most popular ways to increase the market share of meat products is marination, which enhances aroma and flavor, corrects color defects, improves tenderness, etc. (Barbanti \& Pasquini, 2004). Various marination ingredients, such as salts, phosphates, acids, sugar, aroma, flavors, and antioxidants are available in the market (Parks et al., 2000; Barbanti \& Pasquini, 2004; Lyon et al., 2005; Goli et al., 2006; Alvarado and McKee, 2007; Smith and Young, 2007).

Antioxidants are substances that occur naturally in fruits and vegetables and block free radicals in foods, helping to extend their shelf life and to maintain their quality during their life-cycle and in the body cells, protecting consumers' health and preventing diseases, such as cancer, cardiovascular diseases, diabetes, etc. (Hertog et al., 1993; McLarty, 1997; Weisburger, 1999; Pokorny, 2001; Virgili \& Scaccini, 2001).

In recent years, there is growing body of research on natural antioxidant sources, antioxidant compounds, relationship between antioxidants and good health, and effects of antioxidants on food quality. Therefore, the aim of this study was to investigate the effect of marination with mixed vegetable juice, black mulberry juice, red grape juice, black carrot juice and pomegranate juice on the phenolic content, chemical, textural, and sensorial properties of turkey breast meat.

\section{MATERIALS AND METHODS}

\section{Sampling}

Boneless turkey breast meat was obtained from a commercial poultry processing plant (Bolca Hindi, Bolu, Turkey). The turkey breast meat was cut into $1.5-\mathrm{cm}$ thick, 13-cm long slices weighing $200 \mathrm{~g}$. A commercial mixed vegetable juice (Sunpride Co., Bursa, Turkey), consisting of seven different vegetable juices (carrot, tomato, zucchini, black carrot, cucumber and lettuce) was purchased. Pure black mulberry juice, red grape juice, black carrot juice, and pomegranate juice were obtained from a local manufacturer (Targid Food and Agricultural Prods. Inc, Mersin, Turkey) and contained no additives. Distilled water was added to pure juices to produce marinades adjusted to $14^{\circ}$ brix.

\section{Marination}

Meat slices were randomly immersed in the marinade solutions at the ratio of 1:1 (meat:marinade) in plastic bags, and stored at $+4{ }^{\circ} \mathrm{C}$ for 24 hours or 48 hours. The control treatments contained only distilled water.

\section{Phenolic content}

The phenolic content of the marinades and of the turkey breast meat after marination was analyzed using Folin Ciocalteu Calorimetric Method (Singleton and Rossi, 1965), and read at $765 \mathrm{~nm}$ wave length in a spectrometer (Shimadzu UV-1601, Kyoto, Japan).

\section{Meat pH}

The $\mathrm{pH}$ of the turkey breast meat and of the marinades was measured before and after marination (Landvogt, 1991). The $\mathrm{pH}$ was measured in a homogenate prepared by blending $10 \mathrm{~g}$ of sample with $90 \mathrm{~mL}$ of distilled water for $30 \mathrm{~s}$. Readings were made using a WTW, model pH 521, digital pH-meter and a WTW, type E56, combination electrode (WTW - Wissensehaftlich-Technische Werkstaetten GmbH, Weilheim, Germany).

\section{Moisture content}

Moisture content (\%) of the samples was determined according to standard procedures pf the AOAC (1990).

\section{Cooking loss}

After marination for 24 hours or 48 hours, samples were allowed to drain for 10 minutes at room temperature and then placed on trays lined with aluminum foil. Samples were cooked for 30 minutes in a convection oven (Beko, Istanbul, Turkey) at $150^{\circ} \mathrm{C}$. Cooking loss was calculated as the weight difference before and after cooking.

\section{Color measurement}

After marination and cooking, samples were placed into the clear petri dishes, and then Hunter Lab parameters $\left(L^{*}, a^{*}\right.$, and $\left.b^{*}\right)$ were measured on the surface of the samples using a colorimeter (Minolta, model CR 400, Osaka, Japan).

\section{Texture profile analysis (TPA)}

TPA parameters of the samples, including hardness (peak force on first compression), adhesiveness (the time that the samples remained adhered to the probe), cohesiveness (positive force ratio between the second and first compression cycle), and chewiness (energy needed to chew a solid sample to a steady state of swallowing) were determined according to the procedures suggested by Bourne (1978) and Ruiz de Huidobro et al. (2005). TPA tests were performed 
using a Texture Analyzer (TA-XT plus, Stable Micro Systems Ltd., UK) and following specifications were applied: cylindrical probe with $35-\mathrm{mm}$ diameter, 50$\mathrm{kg}$ maximum cell loading, $1 \mathrm{~mm} / \mathrm{s}$ velocity before the test and $5 \mathrm{~mm} / \mathrm{s}$ velocity during and after the test, 5 $\mathrm{g}$ trigger force. Samples measuring $1 \times 1 \times 1 \mathrm{~cm}^{3}$ were analyzed and five replicate measurements were carried out for each sample.

\section{Sensory evaluation}

Sensory panel was performed in two steps. The pre-trial panel and the experimental panel consisted of 10 trained panelists from Afyon Kocatepe University, Food Engineering Department. Each marinated sample was cut into $2.00 \times 2.00 \times 2.00 \mathrm{~cm}$ pieces and randomly identified with three-digit-codes. The samples were served to the panelists under artificial light (incandescent) at room temperature $\left(22^{\circ} \mathrm{C}\right)$ in a random order on the same occasion. Apple juice and bread were offered between samplings to neutralize the residual flavor under fluorescent light. Samples were scored as follows: 7-8 very good, 4-6 good, and 1-3 very bad.

\section{Statistical analysis}

Data were analyzed by one-way analysis of variance using the software SPSS 8.0 for Windows. Means were compared by the least significant difference (LSD) test $(p<0.05)$.

\section{RESULTS AND DISCUSSION}

The phenolic content of the marinade solutions and the turkey breast meat after marination for 24 or 48 hours are presented in Table 1. Samples marinated in pomegranate juice presented the highest phenolic content (1354.76 mg ga/L), whereas mixed vegetable juice (2150.6 mg ga/L) and samples marinated in mixed vegetable juice $(250.12 \mathrm{mg} \mathrm{ga} / \mathrm{L})$, the lowest phenolic content $(p<0.05)$. The phenolic content of the samples after marination was lower than that of untreated marinade solutions. The decrease in phenolic content of the meat samples after marination may be explained by the conversion of phenolic substances from insoluble into soluble forms due to oxidation reactions, as suggested by Bravo (1988). The phenolic content of the samples marinated for 24 hours was higher than of those marinated for 48 hours, possibly because it is difficult to analyze insoluble phenolic substances as marination time increases.
Table 1 - Phenolic content of the marinate solutions and turkey breast meat after marination for 24 and 48 hours (mg ga/L).

\begin{tabular}{lccc}
\hline Marinade & $\begin{array}{c}\text { Marinade } \\
\text { solution }\end{array}$ & 24 Hour & 48 Hour \\
\hline Mixed Vegetable & $2150.56^{\mathrm{e}}$ & $250.12^{\mathrm{e}}$ & $210.56^{\mathrm{e}}$ \\
Black Mulberry & $10895.16^{\mathrm{b}}$ & $1210.45^{\mathrm{b}}$ & $1022.16^{\mathrm{b}}$ \\
Red Grape & $9600.50^{\mathrm{c}}$ & $1120.16^{\mathrm{c}}$ & $985.15^{\mathrm{c}}$ \\
Black Carrot & $4800.12^{\mathrm{d}}$ & $368.14^{\mathrm{d}}$ & $318.97^{\mathrm{d}}$ \\
Pomegranate & $12232.66^{\mathrm{a}}$ & $1354.76^{\mathrm{a}}$ & $1156.43^{\mathrm{a}}$ \\
\hline
\end{tabular}

Means within a column with different letters are significantly different $(p<0.05)$.

The $\mathrm{pH}$ values of the marinade solutions before and after marination for 24 and 48 hours are shown in Table 2. The $\mathrm{pH}$ values of the marinades were between 3.807.10, with the lowest pH measured in pomegranate juice and the highest in the control solution $(p<0.05)$. Similarly, Obuz \& Cesur (2009) found that the chicken breast meat marinated in pomegranate juice presented the lowest $\mathrm{pH}$ value. The $\mathrm{pH}$ values of the marinade solutions, except for the control solution (distilled water), increased after marination $(p<0.05)$.

Table $2-\mathrm{pH}$ values of the marinade solutions before marination and after marination for 24 and 48 hours.

\begin{tabular}{lccc}
\hline \multirow{2}{*}{ Marinade } & \multicolumn{3}{c}{ Marination time } \\
\cline { 2 - 4 } & 0 Hour & 24 Hour & 48 Hour \\
\hline Control & $7.10^{\mathrm{a}}$ & $6.42^{\mathrm{a}}$ & $6.32^{\mathrm{a}}$ \\
Mixed Vegetable & $4.80^{\mathrm{b}}$ & $5.16^{\mathrm{c}}$ & $5.22^{\mathrm{c}}$ \\
Black Mulberry & $4.50^{\mathrm{b}}$ & $4.81^{\mathrm{e}}$ & $5.17^{\mathrm{c}}$ \\
Red Grape & $4.30^{\mathrm{c}}$ & $5.67^{\mathrm{b}}$ & $5.86^{\mathrm{b}}$ \\
Black Carrot & $4.83^{\mathrm{b}}$ & $4.89^{\mathrm{d}}$ & $5.01^{\mathrm{d}}$ \\
Pomegranate & $3.80^{\mathrm{d}}$ & $4.51^{\mathrm{f}}$ & $4.81^{\mathrm{e}}$ \\
\hline
\end{tabular}

Means within a column with different letters are significantly different $(p<0.05)$.

The $\mathrm{pH}$ values of the marinated turkey breast meat before marination, after marination and after cooking are shown in Figure 1. A significant decrease of the $\mathrm{pH}$ values of the samples marinated for 24 hours was observed, except for the control sample. Marination with acidic fruit juices decreased $\mathrm{pH}$ values of turkey breast meat $(p<0.05)$. Similarly, Serdaroğlu et al. (2007) recorded a decrease in $\mathrm{pH}$ values of turkey breast meat marinated in grapefruit juice and citric acid. Moreover, Ergezer \& Gökçe (2011) concluded that the turkey breast meat marinated in acids had the lowest $\mathrm{pH}$ values. After 48 of marination, the control sample presented the highest $\mathrm{pH}$ value, while samples marinated in the pomegranate juice had the lowest $\mathrm{pH}$ value $(p<0.05)$. In samples marinated for $24 \mathrm{~h}$ and cooked, pH values increased, except for control sample $(p<0.05)$, which may be attributed to the loss of free acidic groups during cooking (Lawrie, 1979). Ergezer \& Gökçe (2011) reported a similar increase in pH values 
of marinated turkey meat after cooking. On the other hand, marination for 48 hours followed by cooking reduced the $\mathrm{pH}$ values of all samples, except for the control sample and the sample marinated in red grape juice.

The moisture content of the turkey breast meat after marination and cooking is presented in Figure 2. After 24 and 48 hours of marination, the moisture content of the samples marinated in juices decreased and then increased. On the other hand, the moisture content of the control samples increased during marination and then decreased. Cooking reduced the moisture content of the samples $(p<0.05)$ possibly due to the breakdown of proteins caused by heating (Huang 2010). Obuz \& Cesur (2009) and Serdaroğlu et al. (2007), evaluating chicken and turkey breast meat, respectively, indicated that the moisture content of the marinated samples was higher than that of marinated + cooked samples.
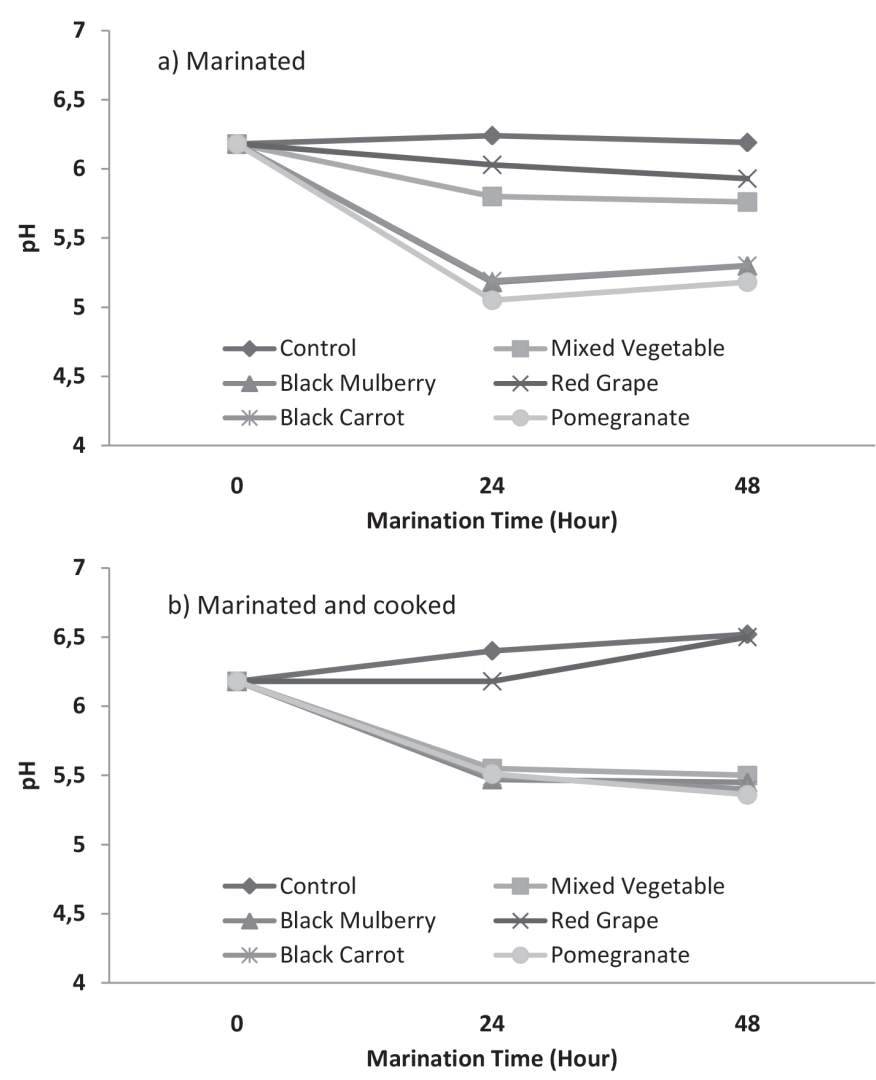

Figure 1 - $\mathrm{pH}$ values of turkey breast meat: a) before marination and after marination for 24-48 hours; b) after cooking.

The moisture content of the samples marinated for 24 hours and cooked varied between 58.85\% and $70.51 \%$, with the highest valued obtained in the control samples $(p<0.05)$ (Figure 2$)$. A similar value was reported cooked chicken meat marinated in water by Obuz \& Cesur (2009). After marination for 48 hours and cooking, the control sample presented the lowest moisture content, while the samples marinated in pomegranate juice presented the highest moisture content $(p<0.05)$.
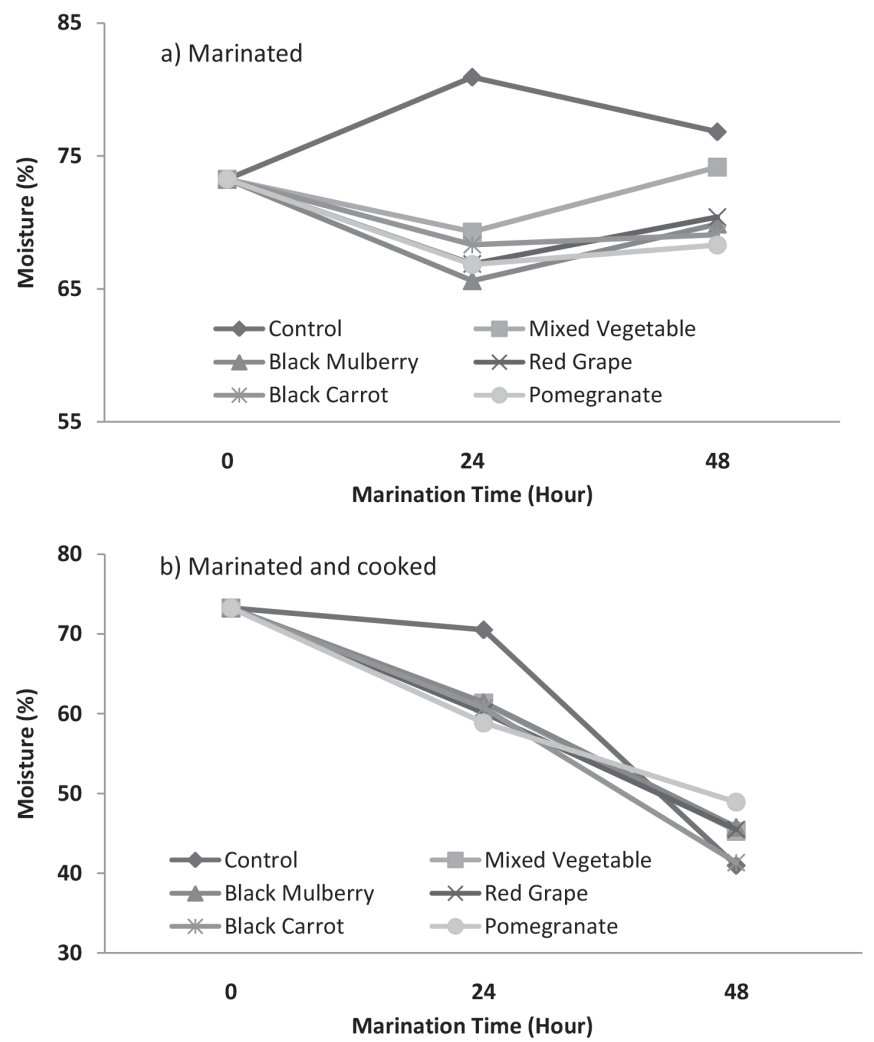

Figure 2 - Moisture content ofturkey breast meata) before marination and after marination for 24-48 hours; b) after cooking.

Figure 3 shows the cooking loss results of the turkey breast meat samples marinated for 24 and 48 hours.

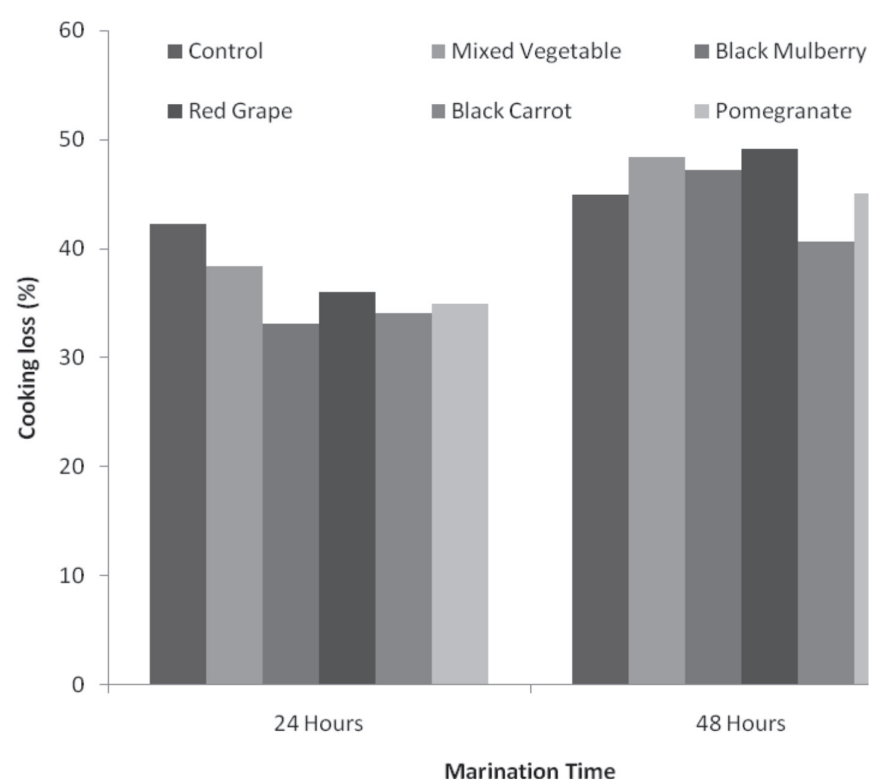

Figure 3 - Cooking losses of turkey breast meat after marination for 24 and 48 hours marination. 
Cooking loss increased with increasing marination time. The samples marinated in red grape juice for 48 hours presented the highest cooking loss (49.11\%), and the lowest was recorded for the samples marinated in black carrot juice (40.61\%). Higher cooking loss values were obtained in the present study than those reported by Serdaroğlu et al. (2007) in turkey meat and Yusop et al. (2010) and Qiao et al. (2002) in chicken meat, and may be attributed to differences in the marination methods and marinade composition.

Color parameters of the samples after marination for 24 and 48 hours are shown in Table 3. Marination significantly affected $L^{*}, a^{*}$, and $b^{*}$ values of the turkey breast samples $(p<0.05)$. After 24 hours of marination, $L$ * values of the samples decreased, except for the control sample. On the other hand, Serdaroğlu et al. (2007) reported that $L^{*}$ values increased when turkey meat samples were marinated in grapefruit juice or citric acid. According to those researchers, one possible reason for increased $L^{*}$ values is that muscle proteins swell and light reflection alters at low pH and ionic strength, resulting in lighter color. The $L^{*}$ values of the control samples and of those marinated with mixed vegetable juice and black carrot juice for 48 hours increased, and decreased in all other samples.

The $a^{*}$ values were affected $(p<0.05)$ by marination. Marination in mixed vegetable, black mulberry, black carrot and pomegranate juices increased a* values as compared to the control sample, whereas red grape juice marination did not affect $a^{*}$ values $(p>0.05)$. Similarly, Obuz \& Cesur (2009) reported an increase in $a^{*}$ values after chicken meat was marinated in fruit juice. On the other hand, Serdaroğlu et al. (2007) indicated that a* values were not affected by marinating turkey breast samples in grapefruit juice and citric acid. After 48 hour marination, the highest a* values were determined for black carrot, which is rich in natural pigments. The $b$ * values of the samples marinated in red grape and black mulberry juices were higher than that of the control sample. Carroll et al. (2007) did not detect any differences on $b$ * values in turkey breast, while Cadun et al. (2008) reported decreased $b$ * values in shrimp.

The effect of cooking on $L^{*}$ values was inconsistent (Table 4). After cooking, the $L^{*}$ values of the samples marinated in mixed vegetable, black carrot, and pomegranate juices and the control samples increased, whereas reduced $L^{*}$ values were recorded in those marinated in black mulberry and red grape juices $(p<0.05)$. While similar results of cooking were reported by Obuz \& Cesur (2009) in chicken breast, they are not in line with the findings of Serdaroğlu et al. (2007) in turkey meat and Qiao et al. (2002) in chicken meat, who reported higher $L^{*}$ values with cooking. Moreover, Smith and Young (2007) found lower $L^{*}$ values in another study with chicken breast fillets.

After cooking, $a^{*}$ values increased, except for the samples marinated in black carrot juice $(p<0.05)$ (Table 4). Ergezer \& Gökçe (2011) attributed similar increase to the formation of lactate and phosphate during cooking. The L* value (lightness) was largely influenced by the color coming from the marinating fruit. In a previous study, we determined that marination in

Table 3 - Color parameters of turkey breast meat after marination for 24 and 48 hours.

\begin{tabular}{|c|c|c|c|c|c|c|}
\hline \multirow{2}{*}{ Marinade } & \multicolumn{2}{|c|}{$L^{*}$} & \multicolumn{2}{|c|}{$a^{*}$} & \multicolumn{2}{|c|}{$b^{*}$} \\
\hline & $24 h$ & $48 \mathrm{~h}$ & $24 h$ & $48 \mathrm{~h}$ & $24 h$ & $48 \mathrm{~h}$ \\
\hline Control & $61.95^{a}$ & $63.08^{a}$ & $7.12^{\mathrm{e}}$ & $7.69^{f}$ & $1.37^{d}$ & $2.87^{d}$ \\
\hline Mixed Vegetable & $20.36^{f}$ & $20.42^{f}$ & $13.99^{b}$ & $12.50^{\mathrm{b}}$ & $-1.05^{f}$ & $-1.91^{f}$ \\
\hline Black Mulberry & $59.85^{b}$ & $56.48^{b}$ & $8.62^{d}$ & $8.65^{e}$ & $15.05^{b}$ & $11.17^{b}$ \\
\hline Red Grape & $56.95^{c}$ & $52.01^{c}$ & $6.77^{f}$ & $9.62^{c}$ & $23.83^{a}$ & $19.27^{\mathrm{a}}$ \\
\hline Black Carrot & $36.50^{e}$ & $42.22^{e}$ & $22.73^{a}$ & $16.50^{a}$ & $0.68^{e}$ & $1.29^{e}$ \\
\hline Pomegranate & $52.39^{d}$ & $49.98^{d}$ & $9.35^{c}$ & $8.90^{d}$ & $4.83^{c}$ & $2.98^{c}$ \\
\hline
\end{tabular}

Means within a column with different letters are significantly different $(p<0.05)$.

Table 4 - Color parameters of turkey breast meat after marination for 24 and 48 hours and cooking.

\begin{tabular}{|c|c|c|c|c|c|c|}
\hline \multirow{2}{*}{ Marinade } & \multicolumn{2}{|c|}{$L^{*}$} & \multicolumn{2}{|c|}{$a^{*}$} & \multicolumn{2}{|c|}{$b^{*}$} \\
\hline & $24 h$ & $48 \mathrm{~h}$ & $24 h$ & $48 \mathrm{~h}$ & $24 h$ & $48 \mathrm{~h}$ \\
\hline Control & $70.43^{a}$ & $73.31^{a}$ & $10.29^{e}$ & $9.65^{b}$ & $12.17^{d}$ & $9.32^{d}$ \\
\hline Mixed Vegetable & $25.25^{f}$ & $21.80^{f}$ & $14.36^{d}$ & $12.00^{\mathrm{ab}}$ & $-0.84^{f}$ & $-0.9^{f}$ \\
\hline Black Mulberry & $58.53^{b}$ & $59.53^{c}$ & $20.05^{\mathrm{a}}$ & $15.60^{\mathrm{ab}}$ & $32.14^{\mathrm{a}}$ & $21.25^{b}$ \\
\hline Red Grape & $43.65^{e}$ & $49.03^{d}$ & $16.13^{c}$ & $12.75^{\mathrm{ab}}$ & $25.67^{b}$ & $26.80^{a}$ \\
\hline Black Carrot & $48.29^{d}$ & $39.62^{e}$ & $17.17^{\mathrm{b}}$ & $17.05^{a}$ & $10.18^{e}$ & $8.03^{e}$ \\
\hline Pomegranate & $57.17^{c}$ & $61.93^{b}$ & $14.41^{d}$ & $13.30^{\mathrm{ab}}$ & $18.33^{c}$ & $10.70^{c}$ \\
\hline
\end{tabular}

Means within a column with different letters are significantly different $(p<0.05)$ 
pomegranate, grape, or sour cherry juices decreased $L^{*}$ values of the chicken breast samples as compared to control, whereas orange or apple juice marination did not affect $L *$ values ( $p>0.05$ ).

While the highest lightness values $\left(L^{*}\right)$ were obtained in the control samples, black carrot marination resulted in the highest $a^{*}$ values before cooking. Differences in $L^{*}$ values after cooking were not significant, as reported by Cadun et al. 2008, Ergezer (2005) and Carroll et al. (2007). Qiao et al. 2002 reported higher $L^{*}$ values after cooking. In another study, Smith and Young (2007) detected lower $L^{*}$ values in marinated raw chicken breast fillets. On the other hand, Northcutt et al. (2000) did not report any significant differences in $L^{*}$ values between marinated and non-marinated raw and cooked chicken fillets.

TPA parameters (hardness, adhesiveness, cohesiveness, and chewiness) of the turkey breast meat samples after marination and marination+cooking are shown in Table 5. Marination with fruit juices and vegetable juices affected hardness, adhesiveness, cohesiveness and chewiness $(p<0.05)$. Mixed vegetable juice marination for 24 hours resulted in higher $(p<0.05)$ hardness values. The lowest hardness values were detected in the samples marinated in pomegranate and red grape juices. Serdaroğlu et al. (2007) also reported lower hardness values in turkey meat marinated in citric acid and grapefruit juice. While the highest hardness value was recorded in the control samples, those marinated in red grape juice presented the lowest value $(p<0.05)$. Cooking increased hardness values $(p<0.05)$. Denaturation of meat proteins and structural changes, such as destruction of cell membranes, shrinkage of meat fibers, aggregation and gel formation of myofibrillar and sarcoplasmic proteins, and shrinkage and solubilization of the connective tissue during heating, result in increased hardness (Tornberg, 2005). Marination reduced adhesiveness values of the samples marinated in pomegranate and red grape juices, while increased values were recorded for those marinated in mixed vegetable, black mulberry, and black carrot juices $(p<0.05)$. Lower chewiness values are directly correlated with higher meat tenderness, and contributes for better consumer perception of the final product. Contrary to results after 24 hours marination, chewiness values of the samples marinated for 48 hours were lower than those of the control sample. Marination for 48 hours positively affected hardness and chewiness values. Obuz \& Cesur (2009) also reported decreased chewiness values of chicken breast meat after marination $(p<0.05)$.

Sensory analysis results of marinated turkey breasts are given in Table 6 . Marination affected $(p<0.05)$ the appearance, odor, juiciness, flavor, tenderness, and general acceptability of the samples as judged by the sensory panel. On a given marination time, turkey breast meat marinated in mixed vegetable juice and in the control solutions were given the highest $(p<0.05)$ appearance scores (Table 6). The flavor scores of turkey breast samples marinated in all marinade solutions were higher than those of control $(p<0.05)$. The lowest odor score was given to control samples, whereas the highest tenderness score was given to samples marinated in mixed vegetable juice. In terms of flavor and general acceptability scores, turkey breast meat marinated in mixed vegetable and red grape juices were given the highest scores by the sensory panel in our study (Table 6).

The samples marinated for 48 hours were the most preferable $(p<0.05)$. Ergezer \& Gökçe (2011) reported higher juiciness and flavor scores after marination. According to Obuz \& Cesur (2009), lower flavor

Table 5 - Textural properties of turkey breast meat after marination for 24 and 48 hours and cooking.

\begin{tabular}{|c|c|c|c|c|c|c|c|c|c|}
\hline & \multirow{2}{*}{ Marinade } & \multicolumn{2}{|c|}{ Hardness } & \multirow[b]{2}{*}{$24 \mathrm{~h}$} & \multirow[b]{2}{*}{$48 \mathrm{~h}$} & \multirow[b]{2}{*}{$24 h$} & \multirow[b]{2}{*}{$48 h$} & \multirow[b]{2}{*}{$24 h$} & \multirow[b]{2}{*}{$48 h$} \\
\hline & & $24 h$ & $48 h$ & & & & & & \\
\hline \multirow{6}{*}{ 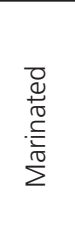 } & Control & $1.43^{c}$ & $3.32^{a}$ & $0.44^{d}$ & $0.90^{\mathrm{a}}$ & $0.24^{c}$ & $0.32^{b}$ & $0.35^{c}$ & $1.06^{a}$ \\
\hline & Mixed Vegetable & $2.78^{a}$ & $2.54^{b}$ & $1.02^{\mathrm{a}}$ & $0.72^{c}$ & $0.25^{b}$ & $0.32^{\mathrm{a}}$ & $0.68^{a}$ & $0.84^{b}$ \\
\hline & Black Mulberry & $1.23^{d}$ & $2.31^{c}$ & $0.69^{c}$ & $0.78^{b}$ & $0.23^{d}$ & $0.26^{c}$ & $0.29^{d}$ & $0.61^{c}$ \\
\hline & Red Grape & $1.22^{d}$ & $0.81^{f}$ & $0.38^{e}$ & $0.36^{e}$ & $0.23^{d}$ & $0.25^{d}$ & $0.28^{e}$ & $0.19^{f}$ \\
\hline & Black Carrot & $2.38^{b}$ & $1.01^{\mathrm{e}}$ & $0.81^{b}$ & $0.31^{f}$ & $0.25^{\mathrm{a}}$ & $0.24^{\mathrm{e}}$ & $0.60^{b}$ & $0.26^{e}$ \\
\hline & Pomegranate & $1.24^{d}$ & $1.36^{d}$ & $0.36^{e}$ & $0.42^{d}$ & $0.21^{e}$ & $0.23^{f}$ & $0.27^{f}$ & $0.31^{d}$ \\
\hline \multirow{6}{*}{ 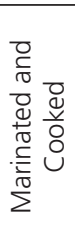 } & Control & $6.34^{c}$ & $6.40^{a}$ & $3.70^{c}$ & $8.83^{b}$ & $0.17^{d}$ & $0.21^{a}$ & $1.09^{a}$ & $1.31^{\mathrm{a}}$ \\
\hline & Mixed Vegetable & $4.57^{d}$ & $4.91^{c}$ & $2.46^{f}$ & $7.77^{c}$ & $0.20^{b}$ & $0.18^{d}$ & $0.87^{b}$ & $0.89^{c}$ \\
\hline & Black Mulberry & $5.79^{e}$ & $3.81^{e}$ & $3.30^{d}$ & $7.70^{c}$ & $0.18^{c}$ & $0.19^{b}$ & $1.05^{a}$ & $0.74^{\mathrm{e}}$ \\
\hline & Red Grape & $8.25^{a}$ & $3.96^{d}$ & $4.90^{\mathrm{a}}$ & $6.63^{e}$ & $0.21^{a}$ & $0.19^{c}$ & $0.94^{b}$ & $0.74^{d}$ \\
\hline & Black Carrot & $6.36^{c}$ & $5.84^{b}$ & $2.92^{\mathrm{e}}$ & $10.65^{a}$ & $0.21^{\mathrm{a}}$ & $0.19^{b}$ & $1.36^{\mathrm{a}}$ & $1.14^{b}$ \\
\hline & Pomegranate & $7.38^{b}$ & $4.03^{d}$ & $3.82^{b}$ & $6.91^{d}$ & $0.19^{b}$ & $0.18^{e}$ & $1.42^{a}$ & $0.71^{f}$ \\
\hline
\end{tabular}

Means within a column with different letters are significantly different $(p<0.05)$. 
Table 6 - Scores given by the sensorial panel to the marinated turkey breast meat.

\begin{tabular}{|c|c|c|c|c|c|c|c|}
\hline Marinade & Marination Time & Appearance & Odor & Juiciness & Flavor & Tenderness & $\begin{array}{c}\text { General } \\
\text { Acceptance }\end{array}$ \\
\hline \multirow[t]{2}{*}{ Control } & 24 Hour & $7.75^{a}$ & $5.40^{c}$ & $5.60^{b}$ & $4.20^{d}$ & $4.20^{c}$ & $4.20^{c}$ \\
\hline & 48 Hour & $6.60^{\mathrm{bc}}$ & $5.40^{c}$ & $5.20^{c}$ & $4.80^{d}$ & $4.80^{e}$ & $4.60^{d}$ \\
\hline \multirow[t]{2}{*}{ Mixed Vegetable } & 24 Hour & $7.80^{\mathrm{a}}$ & $7.20^{\mathrm{a}}$ & $6.80^{\mathrm{a}}$ & $7.80^{\mathrm{a}}$ & $7.20^{\mathrm{a}}$ & $6.60^{a}$ \\
\hline & 48 Hour & $7.60^{a}$ & $7.45^{a}$ & $7.60^{a}$ & $8.00^{a}$ & $7.40^{\mathrm{a}}$ & $7.60^{\mathrm{a}}$ \\
\hline \multirow[t]{2}{*}{ Black Mulberry } & 24 Hour & $6.80^{\mathrm{b}}$ & $6.80^{\mathrm{ab}}$ & $6.40^{\mathrm{ab}}$ & $5.60^{c}$ & $6.20^{\mathrm{b}}$ & $6.40^{a}$ \\
\hline & 48 Hour & $6.40^{\mathrm{bc}}$ & $6.60^{\mathrm{ab}}$ & $6.20^{b}$ & $7.00^{b}$ & $6.00^{d}$ & $6.60^{c}$ \\
\hline \multirow[t]{2}{*}{ Red Grape } & 24 Hour & $6.60^{\mathrm{b}}$ & $7.00^{\mathrm{a}}$ & $6.00^{\mathrm{ab}}$ & $7.20^{\mathrm{b}}$ & $6.00^{\mathrm{b}}$ & $6.40^{\mathrm{a}}$ \\
\hline & 48 Hour & $7.20^{\mathrm{ab}}$ & $7.00^{\mathrm{a}}$ & $7.40^{\mathrm{b}}$ & $6.80^{b}$ & $7.20^{\mathrm{ab}}$ & $7.40^{\mathrm{ab}}$ \\
\hline \multirow[t]{2}{*}{ Black Carrot } & 24 Hour & $5.60^{c}$ & $6.40^{b}$ & $6.00^{\mathrm{ab}}$ & $5.60^{c}$ & $6.20^{\mathrm{b}}$ & $6.20^{\mathrm{a}}$ \\
\hline & 48 Hour & $5.80^{c}$ & $5.80^{\mathrm{bc}}$ & $6.20^{\mathrm{b}}$ & $5.80^{c}$ & $7.00^{\mathrm{bc}}$ & $7.20^{\mathrm{b}}$ \\
\hline \multirow[t]{2}{*}{ Pomegranate } & 24 Hour & $5.40^{c}$ & $6.80^{\mathrm{ab}}$ & $5.60^{b}$ & $4.60^{d}$ & $5.40^{\mathrm{b}}$ & $5.40^{\mathrm{b}}$ \\
\hline & 48 Hour & $6.20^{\mathrm{bc}}$ & $6.60^{\mathrm{ab}}$ & $6.00^{\mathrm{bc}}$ & $5.80^{c}$ & $6.80^{c}$ & $6.80^{c}$ \\
\hline
\end{tabular}

Means within a row with different letters are significantly different $(p<0.05)$.

scores were related to sourness of chicken breast meat marinated in fruit juice. Other authors (Scanga et al., 2000; Robbins et al., 2003; Hoffman, 2006; Xiong \& Kupski, 2000; Frogning \& Sackett, 1985) reported that marinated meat products were scored more preferable than the control samples after 24 marination. Increased marination time caused an increase in the general acceptance score of the samples. While the control sample was the least preferred sample, the sample marinated in mixed vegetable juice was the most preferred one.

\section{CONCLUSIONS}

As marination of the turkey breast meat in pomegranate and red grape juices decreased hardness values, these juices may be used as natural tenderness agents in marination processes. Marination for 48 hours resulted in better textural quality of the turkey breast meat than marination for 24 hours. Marinated samples were preferred over the control samples, and the samples marinated in vegetable juice were given the highest acceptance score. Marination with different fruit and vegetable juices should be researched to further improve turkey meat quality.

\section{REFERENCES}

AOAC - Association of Official Analytical Chemists. Official methods of analysis. 15th ed. Washington; 1990.

Alvarado C, Mckee S. Marinaton to improve functional properties and safety of poultry meat. Journal of Applied Poultry Research 2007;16:113-120.

Barbanti S, Pasquini M. Influence of cooking conditions on cooking loss and tenderness of raw and marinated chicken breast meat. Food Science \& Technology 2004;38:895-901.

Bourne MC. Texture profile analysis. Food Technology 1978;32:62-66.
Cadun A, Kişla D, Çakli ş. Marination of deep-water pink shrimp with rosemary extract and the determination of its shelf-life. Food Chemistry 2008;109:81-87.

Carroll CD, Alvarado CZ, Brashears MM, Thompson LD, Boyce J. Marination of turkey breast fillets to control the growth of Listeria monocytogenes and improve meat quality in deli loaves. Poultry Science 2007;86:150155.

Ergezer H. Chemical, microbiological, textural and sensory properties of poultry meats with different methods [thesis]. Denizli (TR): University of Pamukkale, Institute of Natural and Applied Science; 2005.

Ergezer H, Gökçe R. Comparison of marinating with two different types of marinade on some quality and sensory characteristics of turkey breast meat. Journal of Animal and Veterinary Advances 2011;10(1):60-67.

Goli T, Nakhoul PA, Zakhia-Rozis N, Trystram G, Bohuon P. Chemical equilibrium of minced turkey meat in organic solutions. Meat Science 2006;75:308-314

Hertog MGL, Fesrens EJM, Hollman PCK, Katan MB, Kromhou D. Dietary antioxidant flavonoids and risk of coronary heart disease: the zutphen elderly study. Lancet 1993;342:1007-1011.

Hoffman LC. Sensory and physical characteristics of enhanced vs. nonenhanced meat from mature cows. Meat Science 2006;72:195-202.

Huang F, Huang M, Xu X, Zhou G. Influence of heat on protein degradation, ultrastructure and eating quality indicators of pork. Journal of the Science of Food and Agriculture 2010;91:3.

Frogning GW, Sackett B. Effect of salt and phosphates during tumbling of turkey breast muscle on meat characteristics. Poultry Science 1985;64:1328-1333.

İşeri Ö. Hindi etinin beslenmedeki yeri ve önemi. Veteriner Tavukçuluk Derneği Dergisi 2007;5(4):1-4.

Landvogt $\mathrm{A}$. Errors in $\mathrm{pH}$ measurement of meat and meat products by dilution effects. Proceedings of the 37th International Congress of Meat Science and Technology; 1991; Kulmbach. Germany. p.11591162.

Lawrie RA. Meat science. 3rd ed. Oxford: Pergamon Press; 1979

Lyon BG, Smith DP, Savage EM. Descriptive sensory analysis of broiler breast fillets marinated in phosphate, salt, and acid solutions. Poultry Science 2005;84:345-349

Masiero L. Nutritional qualities of turkey meat. World Poultry Misset 1993;9:42-43 
Mclarty JW. Antioxidants and cancer: the epidemiogical evidence. In: Garewal HS, editor. Antioxidants and disease prevention. Boca Raton: CRC Press; 1997. p.45-65.

Northcutt JK, Smith DP, Buhr RJ. Effects of bruising and marination on broiler breast fillet surface appearance and cook yield. Journal of Applied Poultry Research 2000;9:21-28.

Obuz E, Cesur E. Effects of marinating on different properties on chicken breast meat. Fleischwirtschaft 2009;89:95-99.

Parks SS, Reynolds AE, Wickert L. Aqueous apple flavoring in breast muscle has physical, chemical, and sensory properties similar to those of phospate-marinated controls. Poultry Science 2000;79:1183-1188.

Pokorny J. Introduction. Antioxidants in food: practical applications. Boca Raton: CRC Press; 2001.

Qiao M, Fletcher DL, Smith DP, Northcutt JK. Effects of raw broiler breast meat color variation on marination and cooked meat quality. Poultry Science 2002;81:276-280.

Robbins K, Jensen J, Ryan KJ, Homco-Ryan C, Mckeith FK, Brewer MS. Consumer attitudes towards beef and acceptability of enhanced beef. Meat Science 2003;65:721-729.

Ruiz De Huidobro F, Miguel E, Blazquez B, Onega E. A comparison between two methods (Warner-Bratzler and texture profile analysis) for testing either raw meat or cooking meat. Meat Science 2005;69:527-536.

Scang JA, Delmore RJ, Ames RP, Belk KE, Tatum JD, Smith GC. Palatability of beef steaks marinated in solutions of calcium chloride, phospate, and (or) beef-flavoring. Meat Science 2000;55:397-401.

Serdaroğlu M, Abdraimov K, Önenç A. The effects of marinating with citric acid solutions and grapefruit juice on cooking and eating quality of turkey breast. Journal of Muscle Foods 2007;18:162-172.
Singleton VL, Rossi JR. Colorimetry of total phenolics with phosphomolibdicphosphothungstic acid. American Journal of Enology and Viticulture 1965;16:144-158

Sipahi C. Türkiye' de entansif hindi yetiştiriciliği. Veteriner HekimLer Derneği Dergisi 2006;77(4):17-21.

Smith DP, Young LL. Marination pressure and phosphate effects on broiler breast filet yield, tenderness, and color. Poultry Sciene 2007;86:26662670.

Stadelman WJ, Olson VM, Shemwell GA, Pasch S. Nutritional value of poultry meat. In: Morton ID, Scott R, Watson DH, Lewis MG, editor. Egg and poultry- meat processing. Chichester: Ellis Horwood; 1988. p.92-122.

Tornberg E. Effects of heat on meat proteins: Implications on structure and quality of meat products. Meat Science 2005;70:493-508.

Virgili F, Scaccini C. Cardiovascular disease and nutritional phenolics. In: Pokorny J, Yanislieva N, Gordon M, editors. Antioxidants in food: practical applications. Cambridge: Woodhead Publishing; 2001. p.8789.

Weisburger $\mathrm{JH}$. Mechanisms of action of antioxidants as exemplified in vegetables, tomatoes and tea. Food and Chemical Toxicology 1999;37:943-948

Xiong YL, Kupski DR. Time-dependent marinade absorption and retention, cooking yield, and palatability of chicken fillets marinated in various phosphate solutions. Poultry Science 1999;78:1053-1059.

Yusop SM, O'sullivan MG, Kerry JF, Kerry JP. Effect of marinating time and low $\mathrm{pH}$ on marinade performance and sensory acceptability of poultry meat. Meat Science 2010;85(4):657-663. 